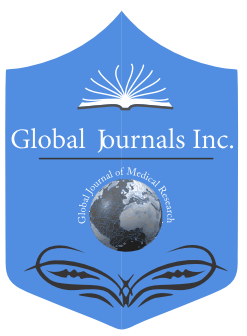

\title{
Preliminary Phytochemical Analysis of a Polyherbal Siddha Formulation Milagu Leghium (Ml)
}

By Subathra D \& Kirubakaran R

Ramavana Siddha Speciality Centre

Abstract- Legiyam is one of the sublime formulations of internal medicine in the Siddha system. Milagu legiyam is a polyherbal formulation that is indicated for vatha disease. athmaratchamirtham is the literature evidence for this drug. The purpose of this paper is to prove the ML contains the bioactive components which were used for the above indication.

Keywords: arthritis, phytochemical, pepper.

GJMR-B Classification: NLMC Code: WB 925

Strictly as per the compliance and regulations of:

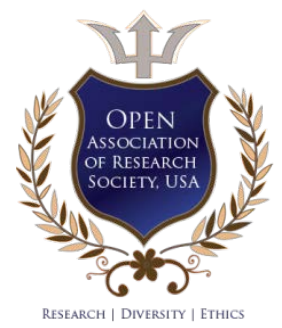

(C) 2020. Subathra D \& Kirubakaran R. This is a research/review paper, distributed under the terms of the Creative Commons Attribution-Noncommercial 3.0 Unported License http://creativecommons.org/licenses/by-nc/3.0/), permitting all non-commercial use, distribution, and reproduction in any medium, provided the original work is properly cited. 


\title{
Preliminary Phytochemical Analysis of a Polyherbal Siddha Formulation Milagu Leghium (MI)
}

\author{
Subathra $D^{\alpha} \&$ Kirubakaran $\mathrm{R}^{\sigma}$
}

Abstract-Legiyam is one of the sublime formulations of internal medicine in the Siddha system. Milagu legiyam is a polyherbal formulation that is indicated for vatha disease. athmaratchamirtham is the literature evidence for this drug. The purpose of this paper is to prove the ML contains the bioactive components which were used for the above indication.

Keywords: arthritis, phytochemical, pepper.

\section{INTRODUCTION}

$\mathrm{n}$ siddha arthritis is being compared to vatha disease. Arthritis is one of the devastating illnesses which generally affect the people in the prevailing situation. So the management and treatment of this disease are important. In Siddha therapeutics are classified into internal \& external. legiyam is one of the internal medicine. A Siddha literature athmaratchamirtham specifies a polyherbal formulation milagu legiyam for vatha disease. Hence we have selected this polyherbal formulation to evaluate the Phytochemical analysis to conclude the bioactive components which have the synergic anti-inflammatory \& antioxidant activity.

\section{il. Materials and Methods}

a) Source and authentication of raw drugs

The required drugs for preparations of $M L$ are purchased from an authorized center. Drugs are identified and authenticated by the Medicinal Botanist of Govt. Siddha Medical College, Palayamkottai, then they are purified, and the medicine was prepared at the P.G.Gunapadam Practical hall of Govt. Siddha Medical College, Palayamkottai.

\section{Ingredients}

\begin{tabular}{|c|c|c|c|c|}
\hline Sl. No. & Drugs & Botanical Name & Part Used & Amount \\
\hline 1 & Milagu & Piper nigrum & Seed & 100palam 3500grams) \\
\hline 2 & Akirakaram & Anacyclus pyrethrum & Root & 1 palam (35 rams) \\
\hline 3 & Seeragam & Cuminum Cyminum & Seed & 1 palam 35grams) \\
\hline 4 & Kirambu & Syzygium aromaticum & Flower & 1 palam (35 rams) \\
\hline 5 & Vaividangam & Emblica ribes & Seed & 1 palam 35grams) \\
\hline 6 & Aelam & Eletaria cardamomum & Unriped fruit & 1 palam (35grams) \\
\hline 7 & Kostam & Costus speciosus & Root & 1 palam(35 grams) \\
\hline 8 & Atimaduram & Glycyrrhiza glabra & & 1 palam(35grams) \\
\hline 9 & Paththiri & Myristica fragrans & Root & 1 palam(35grams) \\
\hline 10 & Narukkumoolam & Piper longum & - & 10 palam(350gram) \\
\hline 11 & Karkandu & - & &
\end{tabular}

b) Purification of raw drugs

Milagu: Soak in butter milk for three days. Then fry in the clay plate.

Akirakaram: Remove the adulterant and make it dry on the shade light.

Seeragam: Soak in $\mathrm{Ca}(\mathrm{OH})_{2}$ water on 21 hours then dried in sun light.

Kirambu: Remove the adulterant and fry it.

vaividangam: Remove the adulterant and make it dry on the shade light

Aelam: Remove the adulterant and fry it

Thippli: Remove the adulterant and fry it

Omam: Soak in $\mathrm{Ca}(\mathrm{OH})_{2}$ water on 3 hours then sun dried

Kostam: Just remove the adulterant and make it dry on the shade light

Thippili moolam: Just remove the adulterant and make it dry on the sun light.

Jathipathiri: Just remove the adulterant and make it dry on the shade light. 


\section{c) Method of preparation}

Take the above raw drugs are powdered separately except pepper, mixed all together. Pepper is crushed and added to 1 Thooni (21.5Lit.) of water and make a Decoction (1:8), ten Palam (350g) of Rock sugar is added to the above decoction and make the sugar solution. Add the powdered raw drugs to the sugar solution stir well. Add 1padi (1400 ml) Ghee and stir well until it reaches the required consistency. Add $1 / 2$ Padi (700 $\mathrm{ml})$ honey and blend well. Store it in a separate dry airtight container.

\section{ili. Determination of Extractable METHOD}

Method Determination of water- soluble extraction

$5 \mathrm{gm}$ of the ML macerated with100 $\mathrm{ml}$ distilled water in a closed flask for $24 \mathrm{hrs}$, shaken frequently for the first six hours in the shaker, and allowed to stand for the next $18 \mathrm{hrs}$. The macerate should be filtered rapidly, taking precautions against loss of solvent.25 $\mathrm{ml}$ of this filtrate is evaporated to dryness in a flat bottom shallow dish and dried at 105 Celsius and collected the extract is used for the phytochemical analysis.

\section{Procedure}

\section{Qualitative Result:}

a) Test for Carbohydrates

Benedict's test: To $0.5 \mathrm{ml}$ of test drug, about 0.5 $\mathrm{ml}$ of Benedict's reagent was added to it. The mixture was heated in a boiling water bath for 2 minutes. A characteristic colourd precipitate indicates the presence of sugar.

\section{b) Glycosides}

Keller-Killiani Test: $2 \mathrm{ml}$ of the extract, glacial acetic acid, one drop 5\% $\mathrm{FeCl}_{3}$ and concentrated $\mathrm{H}_{2} \mathrm{SO}_{4}$ was added. The reddish brown colour appeared at the junction of two liquid layers, and the upper layer turned bluish-green indicating the presence of glycosides.

\section{c) Steroids}

Salkowski Test: $2 \mathrm{ml}$ of extract, $2 \mathrm{ml}$ of chloroform, and $2 \mathrm{ml}$ of concentrated. $\mathrm{H}_{2} \mathrm{SO}_{4}$ was added. The solution was shaken by well. As a result chloroform layer turned red and acid layer shows greenish-yellow fluorescence.

\section{d) Alkaloids}

The extract was evaporated at a test tube. To the residue, dilute HCL was added, shaken well, and filtered.

\section{e) Flavonoids}

Shinoda Test: To the extract, $5 \mathrm{ml}$ of $95 \%$ ethanol and few drops of concentrated hydrochloric acid was added into it. To this solution $0.5 \mathrm{gm}$ of magnesium turnings were added. Pink coloration indicated the presence of flavonoids.

\section{f) Tannins}

Mayer's Test: To the 2-3 ml of filtrate Mayer's reagent was added. The formation of yellow precipitate showed the presence of tannins.

\section{g) Lead Acetate Test}

On the addition of lead acetate solution to the extract, white precipitate appeared.

\section{h) Saponin}

Foam Test: Drug extract was shaken vigorously with water. No persistent foam was formed.

\section{i) Protein}

Biuret Test: With $3 \mathrm{ml}$ of the test solution, a few drops of $4 \% \mathrm{NaOH}$ and $1 \%$ CuSO4 solution were added. The tubes were observed for violet or pink color formation.

\section{j) Phenol}

Ferric chloride Test: The extract was diluted to 5 $\mathrm{ml}$ with distilled water. To that a few drop of neutral $5 \%$ ferric chloride solution was added. A dark green colour indicates the presence of phenolic compounds.

\section{k) Glycosides}

$0.5 \mathrm{mg}$ of extract was dissolved in $1 \mathrm{ml}$ of water, and then aqueous $\mathrm{NaOH}$ solution was added. The formation of yellow color indicates the presence of glycosides.

\section{l) Triterpenoids}

To the test solution, $2 \mathrm{ml}$ chloroform was added with few drops of concentrated Sulphuric acid $(3 \mathrm{ml})$ at the side of the test tube. An interface with a reddishbrown coloration was formed if terpenoids constituent is present. 


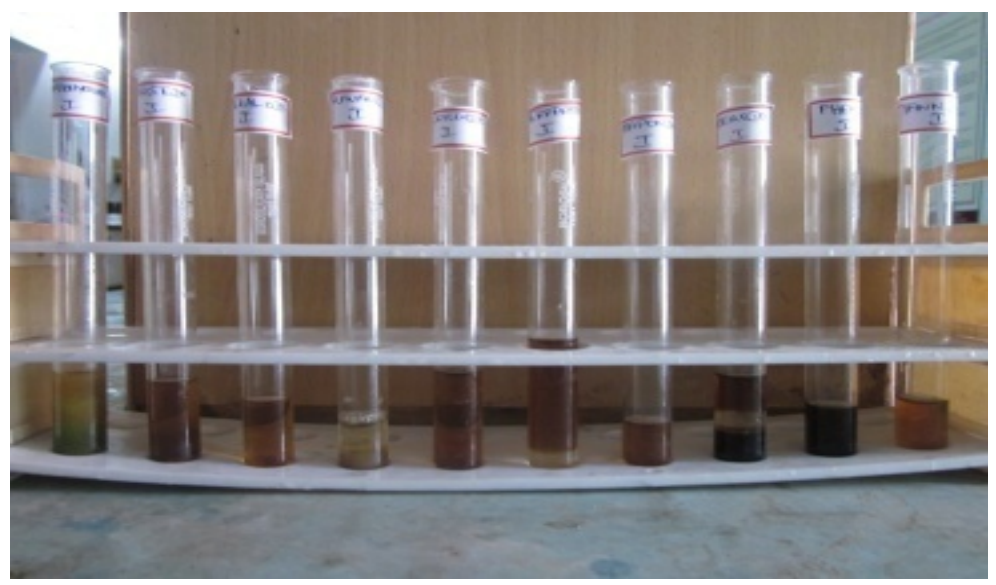

Image 1: Result of preliminary phytochemistry of ML

Table 1: Qualitative Result

\begin{tabular}{|c|c|}
\hline Test Name & ML \\
\hline Carbohydrate & Present \\
\hline Protein & Absent \\
\hline Alkaloid & Present \\
\hline Flavanoid & Present \\
\hline Glycoside & Absent \\
\hline Steroid & Absent \\
\hline Saponin & Absent \\
\hline Phenol & Present \\
\hline Tannin & Absent \\
\hline Terpenoid & Absent \\
\hline
\end{tabular}

\section{Quantitative Result}

a) Procedure

i. Quantitative Estimation of Alkaloids

$1 \mathrm{ml}$ of Methanolic extract $5 \mathrm{ml} \mathrm{pH} 4.7$ phosphate Buffer was being added and $5 \mathrm{ml}$ BCG solution and shaken a mixture with $4 \mathrm{ml}$ of chloroform. The extracts have been collected in a 10-ml volumetric flask and then diluted to adjust volume with chloroform. The absorbance of the complex in chloroform was been measured at $470 \mathrm{~nm}$ against blank prepared as above but without extract. Atropine was been used as a standard material and compared the assay with Atropine equivalents.

\section{ii. Quantitative Estimation of carbohydrate}

Anthrone method (Roe, 1955) was used to estimate the total sugar content. A known amount of the sample have been taken, ground well with $80 \%$ ethanol and it was centrifuged at $4000 \mathrm{rpm}$. From the supernatant, $0.5 \mathrm{ml}$ was taken and $5 \mathrm{ml}$ of the anthrone reagent was added. The tubes were kept in a boiling water bath for $15 \mathrm{~min}$. After that, they were kept in the darkroom for another 15 minutes. The color intensity developed was read in a spectrophotometer at $650 \mathrm{~nm}$.

\section{iii. Quantitative Estimation of flavonoids}

Aluminium chloride method using catechin as a standard was taken as a method to determine the total flavonoid content. $1 \mathrm{ml}$ of the test sample and $4 \mathrm{ml}$ of water were added to a volumetric flask (10 $\mathrm{ml}$ volume). After $5 \mathrm{~min} 0.3 \mathrm{ml}$ of $5 \%$ Sodium nitrite, $0.3 \mathrm{ml}$ of $10 \%$ Aluminium chloride was added. After 6 min it have been kept for incubation at room temperature, $2 \mathrm{ml}$ of $1 \mathrm{M}$ Sodium hydroxide was added to the reaction mixture. Immediately the final volume was been made up to 10 $\mathrm{ml}$ with distilled water. The absorbance of the reaction mixture was been measured at $510 \mathrm{~nm}$ against a blank spectrophotometrically. Results were been expressed as catechin equivalents (mg catechin/g dried extract).

\section{iv. Quantitative Estimation of Saponins}

Methanolic and water extract was dissolved in $80 \%$ methanol, $2 \mathrm{ml}$ of vanillin in ethanol was added, mixed well and the $2 \mathrm{ml}$ of $72 \%$ sulphuric acid solution was added, mixed well and heated on a water bath at $60^{\circ} \mathrm{C}$ for $10 \mathrm{~min}$, absorbance was measured at $544 \mathrm{~nm}$ against reagent blank. The Diosgeninis used as a standard material and compared the assay with Diosgenin equivalents.

\section{v. Quantitative Estimation of Phenolic Compounds}

The total phenolics content in different solvent extracts was determined with the Folin-Ciocalteu's reagent (FCR). In the procedure, different concentrations of the extracts were mixed with $0.4 \mathrm{ml}$ FCR (diluted $1: 10 \mathrm{v} / \mathrm{v}$ ). After $5 \mathrm{~min}, 4 \mathrm{ml}$ of a sodium carbonate solution was added. The final volume of the 
tubes was made up to $10 \mathrm{ml}$ with distilled water and allowed to stand for $90 \mathrm{~min}$ at room temperature. The absorbance of the sample was measured against the blank at $750 \mathrm{~nm}$ using a spectrophotometer. A calibration curve was constructed using Gallic acid solutions as standard (0 to $250 \mu \mathrm{g} / \mu \mathrm{l}$ ).

\section{vi. Total terpenoid determination}

Total terpenoid content was being determined by the method of Ghorai et al, (2012). To $1 \mathrm{~mL}$ of the plant extract, $3 \mathrm{ml}$ of chloroform was added. The sample mixture was thoroughly vortex and left for $3 \mathrm{~min}$, and then $200 \mu \mathrm{l}$ of concentrated sulfuric acid (H2SO4) was added. Then it was being incubated at room temperature for $1.5 \mathrm{~h}-2 \mathrm{~h}$ in dark condition and during incubation, a reddish-brown precipitate was formed. Then carefully and gently, all supernatant of the reaction mixture was decanted without disturbing the precipitation. $3 \mathrm{ml}$ of $95 \%(\mathrm{v} / \mathrm{v})$ methanol was added and www.ijppr.humanjournals.com Citation: Natesan Geetha et al. ljppr. Human, 2015; Vol. 2 (2): 98-106. One hundred vortex thoroughly until all the precipitation dissolves in methanol completely. The absorbance was read at $538 \mathrm{~nm}$ using a UV/visible spectrophotometer. The total terpenoid content was calculated by calibration curve of Linalool and the results were expressed as Linalool equivalent $(\mathrm{mg} / \mathrm{g})$

Table 2: Quantitative result

\begin{tabular}{|c|c|}
\hline Phytochemical & Quantity \\
\hline Carbohydrate & $90 \pm 0.09$ \\
\hline Alkaloid & $74 \pm 0.41$ \\
\hline Flavanoid & $42 \pm 0.28$ \\
\hline Phenol & $60 \pm 0.29$ \\
\hline
\end{tabular}

\section{Result}

The preliminary phytochemistry of the polyherbal formulation ML (aqueous solvent) is done by standard procedure. The results of the qualitative and quantitative bioactive components are presented in Table1 and Table2, respectively. The study discloses Carbohydrate, Alkaloid, Flavonoid, Phenol are the bioactive component present in the ML.

\section{Discussion}

$M L$ is a polyherbal formulation that has indicated for vatha disease in Siddha. The bioactive component present in this formulation poses the activity which was antioxidant and anti-inflammatory. ML containing biochemicals phenol and flavonoid are primary antioxidants. In the human body they prevent the body from the harmful effects of free radicals. Alkaloid poses many medicinal uses that may be having an anti-inflammatory action. Further evolution for isolate the particular alkaloid is needed.

\section{Vili. Conclusion}

Antioxidants are very potent biological active components which are participating in detoxification, cell repair of the body. Otherwise, one most important \& all peoples in our world likes to maintaining our body as younger every day these antioxidants can retain your age by preventing aging. It also strongly reveals a Siddha formulation ML treats and prevents degenerative disorders like age-related arthritis. This phytochemical screening study accepted a remarkable scope to develop a broad use of Siddha medicine and as a base for further researches.

\section{Acknowledgement}

We are first of all, thanks to our parents for supporting this Study. And then thanks to scientific officers in Inbiotic Laboratory for analysis of this Drug $\mathrm{ML}$. And finally, I thank all my friends who have helped this study.

\section{References Références Referencias}

1. Karthigeyan Natarajan, Kabilan Natarajan, Uma et all. 2017. Preliminary phytochemical analysis of a herbal siddha formulation-Roja moggu legiyam.Int. J. of. Current Advanced Research. 6(6):4434-4437.

2. Aathmaratchamirtham page number-445.

3. Mr. Murugesa muthaliyar, Siddha Materia Medica, Indian Medicines and Homeopathy, Chennai.

4. Dr. K. M. Nadkarni, Indian Materia Medica, Vollume II.

5. Dr. S. Somasundaram M.Sc., M.Phil., E.S.M.P., Ph.D., Taxonomy of Angiosperm Part I and Part II.

6. Yugi Vaithiya Chinthamani.

7. Dr. Mayil Vaganan Natarajan. Text book of Orthopaedics and Traumatology. 